\title{
Incessant Insecurity in Nigeria: Has the Country Returned to the State of Nature
}

\author{
Omidoyin Taiye Joshua ${ }^{1}$, Awosusi Bolade Damilola ${ }^{2}$ \\ ${ }^{1}$ College of Law, Achievers University, Owo, Nigeria \\ ${ }^{2}$ Faculty of Law, Federal University, Oye-Ekiti, Nigeria
}

Email address:

omidoyinjoshua@gmail.com (O. T. Joshua)

\section{To cite this article:}

Omidoyin Taiye Joshua, Awosusi Bolade Damilola. Incessant Insecurity in Nigeria: Has the Country Returned to the State of Nature International Journal of Law and Society. Vol. 4, No. 2, 2021, pp. 89-93. doi: 10.11648/j.ijls.20210402.15

Received: April 1, 2021; Accepted: April 19, 2021; Published: May 8, 2021

\begin{abstract}
The rate of insecurity in Nigeria does not only call for concern but raises a loud alarm that no one is safe. The unending occurrence of killing, banditry and kidnapping affect all regions of the country and fear grips the mind of citizens, both the rich and the poor. The government at various levels have tried making security policies, giving security a primary attention in the national budget, purchasing sophisticated ammunitions, reshuffling the rank and file in the army, creating regional security outfits and other proactive steps, yet insecurity in the country prevails by the day and government appears to be handicapped in taking charge of internal sovereignty of the country. The government has however, often times, being excused of liability, especially when the cause of death is not directly connected with any of the government's agencies despite the primary purpose of government is the security and welfare of the citizens. It is in the light of this that the research aims at examining the sole responsibility of government in protecting citizens in the country, and the government's corresponding liability in this regard. Relying on both primary and secondary of information, the article revealed the failure of the government to protect lives and properties within her territory makes the country drift into a state of nature. It is therefore concluded that citizens have entered a social contract for the sake of their safety and security, the government should henceforth be held responsible for further acts of killings and insecurity in the country.
\end{abstract}

Keywords: Insecurity, Human Rights, Government Liability, State of Nature

\section{Introduction}

The relationship between the government and the citizens is one that is traceable to the social contract arrangement wherein Thomas Hobbes, in his book titled "The Leviathan" explained that in order for human beings to escape from the state of nature which is brutal, nasty, solitary and short, there is the need for every human being to submit his or her rights to an organized institution - the government, which in turn will see to the protection of these rights and will protect lives and properties.[1] This social contract arrangement therefore imposes on the government a sacrosanct duty to protect citizens' rights. Hence, human rights are rights inherent in all human beings without prejudice to nationality, gender, place of residence, origin, religion, race or language. These rights can either be individual rights, group rights or peoples' rights. From this analysis, since human beings have rights that must be protected, then an institution must see into this protection, that is the government. Hence, the government is the sole institution to be held accountable for the safety of citizens in the country. Unfortunately, however, the government has often times being excused of liability for insecurity in the country despite the security and welfare of lives and properties remains the primary purpose of government. The citizens have entered a social contract with the government and have surrendered their rights, it is the duty of the government to secure and safeguard these rights in return. [2] Therefore, the incessant rate of insecurity in Nigeria today is uncalled for and the government should wake up to her responsibility in safeguarding citizens lives and properties. 


\section{Government Obligation to Protect Citizens}

The Constitution of the Federal Republic of Nigeria 1999 (As Amended) is the grundnorm of the country and interestingly, the Constitution clearly provides for citizens' rights in the Chapter Four (4) and also government duties in Chapter Two (2). However, for the purpose of this essay, specific sections of Chapter Two (2) and Chapter Four (4) will be examined.

Section 14 (2) (b) of the Constitution [3] provides that the security and welfare of the people shall be the primary purpose of government. Coincidentally, Section 33 of the same Constitution provides that every citizen shall have the right to life and no person's life would be taken unjustly.

As complementary as these provisions may appear theoretically, they are antagonist in reality and the antagonism is created by the Constitution itself, especially in Section 6 (6) (c) wherein the court is ousted of jurisdiction to entertain suits on any matter relating to the provisions on fundamental objectives and directive principles of state policy. In fact, these matters are regarded as been non-justiciable.

Protection of citizens generally implies the protection of citizens' right to life and safety of their properties within the country. Meanwhile, going by the earlier analysed social contract theory, the government is the primary institution saddled with this responsibility of protecting citizens and the government often does this through law enforcement mechanisms. In essence, the government must wade in to protect citizens from threat or any act of hostility that may jeopardise citizens' safety. It does not matter whether the threat is from a private individual, unlawful associations, private institution or even government agency. The state is duty bound to protect all persons within her territory.

Nigeria, for instance, is bedeviled with recurring instances of killings and property destruction arising from political clash, ethnic rivalry, terrorism, banditry, kidnapping, herdsmen attacks, religious conflicts and so on, and these situations are most times unassociated with the act of government, but strictly private conduct of individuals. Even in these circumstances however, the government is still responsible and liable. The reason for this is not farfetched, the government owes a major duty to properly investigate loss of life and set the law in motion for diligent prosecution of all acts of violence and violation of citizens' rights committed within the territory, this is regardless of whether the act is committed by a private institution or not.

This line of reasoning was judicially approved and adopted by the Community Court of Justice of the Economic Community of West African States (ECOWAS) in a suit filed by Mr Obioma Ogukwe [4] where the court succinctly held that the government is duty bound to protect lives of people within its territory, and in the event that there is danger leading to loss of lives, it behooves on the government to investigate the matter properly and bring the culprit to justice. Failure of the government to do so makes the government liable. If the government's law enforcement agency refuses or shabbily investigates any occurrence of loss of life within its territory, the government has failed in its obligation to protect and defend all persons within its territory.

Furthermore, a more practical situation played out in a suit filed by Dorcas Afolalu against the Nigeria Government in 2011 at the ECOWAS Community Court of Justice wherein the plaintiff sought relief for the death of her husband who was brutally murdered during violence that followed the 2011 general elections in Nigeria. The plaintiff, being the wife of the deceased, recounted how her husband was killed and burnt to death by rioters who came to their residence. She consequently blamed the government for the unlawful killing of her husband, and the court agreed with her to the extent that even though the Nigeria Government was not directly the cause of her husband's death yet the government failed in its duty to secure the life of the deceased.

Even recently, the court has expanded the scope and obligation of government to protect citizens even if the citizen is acting in the course of his lawful duties wherein harm or death is foreseeable. The ECOWAS Court of Justice in 2017 invoked the relevant provisions of the African Charter on Human and Peoples Rights to compensate the violation of right to life. Particularly, the father of a deceased cadet in the Nigerian Army approached the court to enforce the right to life of his 19-year-old son who died during the conduct of a waterman-ship training in April, 2015. The plaintiff joined both the Nigerian Government and Nigerian Defence Academy as defendants to the matter. It was the defence of the defendants that the deceased's father had signed a prior agreement consenting to possible negative effects of the exercise, including the hazard involved therein.

The court could not agree with the defendants' position, rather the court found that the death of the deceased is closely linked with the negligence of the defendants. And the mere general denial of the act by the defendants or reference to prior consent agreement does not excuse the defendants from liability. The court further held that the secret agreement does not negate the requirement of carefulness on the defendants to perform any act of reparation to the family of the deceased is condemnable.

From the above case analysis, it becomes crystal clear that the government can be held accountable for failure to protect citizens and the government is even still liable if the cause of death is occasioned by private institution, especially for failure of the government to properly investigate and diligently prosecute.

\section{Potential Rights Violated Through Government's Insensitivity to Protect Citizens}

There are several human rights instruments, both of local, regional and even international level enacted to safeguard 
human existence. These human rights instruments contain different provisions on human rights, ranging from the first generation rights to fourth generation rights for all human beings. No doubt, the Nigerian legal system practices a dualism system of domesticating international law, [5] and the Nigerian government is yet to domesticate or even ratified most third and fourth generation rights, but the first generation rights are sine qua non and inalienable for every citizen and the government is under a non-negotiable obligation to protect them.

In essence therefore, if the government fails in her duty to protect citizens' safety and security, a host of rights becomes violated by the government. These rights include;

1. Right to life which is recognized under Section 33 of the Constitution of the Federal Republic of Nigeria, 1999 (As Amended). This provision clearly stipulates that every person has right to life, hence no one shall be deprived of his right to life unreasonably. Articles 4 of the African Charter on Human and Peoples' Rights (Ratification and Enforcement) Act likewise provides that human beings are inviolable, and every human being shall be entitled to respect for his life and the integrity of his person. The question with an obvious answer therefore is, who is to ensure the protection of these rights and safeguard human life? Apparently, the government. If lives are lost due to government's failure to repair damaged roads and death is caused in the process of citizens plying the road, the government has violated the victim's right to life.

Therefore, for every single human life that is lost unreasonably or unjustly, the government shares in the liability. Also, for every unnaturally occasioned death, the right to life of the deceased as guaranteed by the Constitution and the Africa Charter on Human and Peoples' Rights (Ratification and Enforcement) Act has been violated and the victim is entitled to seek redress.

Furthermore, it is not even until death is occasioned before right to life is violated, if an individual suffers severe injury due to insecurity of life or provision of basic amenities by the government, and he is consequently rendered permanently incapable such that he cannot do anything for his life, livelihood and sustenance, his right to life has been violated. This position of the writer is supported by decisions of the Indian Supreme Court wherein the court defined right to life to include the right to livelihood. The same Indian Supreme Court held in MOHINI JAIN V. STATE OF KARNATAKA [6] that the right to life includes right to live with human dignity and all that goes along with it, namely the basic necessaries of life.

The same reasoning was adopted by the Inter-American Court of Human Rights in THE INDIGENOUS COMMUNITY OF YAKYE AXA V. PARAGUAY, [7] where the court held that the prevention of access to the applicant's traditional means of livelihood was a violation of the right to life. The court has the same reasoning in the STREET CHILDREN CASE that access to the conditions that guarantee dignified existence is part of the right to life, and should particularly be seen in the light of access to means of livelihood. In fact, the court in OLGA TELLIS V. BOMBAY MUNICIPAL CORPORATION, popularly known as the "Pavement Dwellers Case" specifically held that right to livelihood is borne out of the right to life, as no person can live without the means of living, that is, the means of livelihood.

Furthermore, Article 6 (1) of the International Covenant on Civil and Political Rights provides that every human being has the inherent right to life. This right shall be protected by law; no one shall be arbitrarily deprived of his life. Even the English Magna Carta of 1215, one of the earliest international statutes prohibiting deprivation of liberty, states that no free man shall be taken or imprisoned or deceased of his freehold. The European Court further emphasized the need for government to protect human life when it held in MAKARATZIS V. GREECE [8] that the state not only have the duty to refrain from intentional and unlawful taking of life, but also to take appropriate steps within its internal legal order to safeguard the lives of those within its jurisdiction.

The right to life is unarguably the most important of all human rights because it is a pre-condition for the absolute enjoyment of other rights. Little wonder that the right to life is provided in almost all human rights instruments like the Universal Declaration of Human Rights, International Covenant on Civil and Political Rights, African Charter on Human and Peoples' Rights, European Convention on Human Rights, Inter-American Convention on Human Rights and so on.

2. The alarming rate of insecurity caused by government's failure to protect the common masses, but protect politicians and top government officials, is a violation of citizens' right to equality. Article 3 of the African Charter on Human and Peoples' Rights (Ratification and Enforcement) Act specifically provides that every individual shall be equal before the law, and every individual shall be entitled to equal protection of the law. Provision of adequate security should be the overall right of every citizen of the country regardless of class, group, social fortune, status, or political affiliation. Provision of adequate security for a class of people by reason of their status or political affiliation, and abandoning the safety and security of others is a gross violation of right to equality.

More so, Article 6 of the same African Charter on Human and Peoples Rights (Ratification and Enforcement) Act provides that every individual shall have the right to liberty and the security of his person, and to ensure security of persons, the government through the law enforcement agencies should take responsibility for this. This extends to the law enforcement agencies responding promptly and proactively to complaints lodged by citizens and attending to distress calls with dispatch. Meanwhile, since the security outfits of the country are service providers, the citizens should have unhindered access to them as a matter of right. Article 13 (2) of African Charter on Human and Peoples' Rights provides that every citizen shall have the right to the public service of his country.

3. The government's insensitivity to protect the dignity 
inherent in every human being also amounts to the violation of the rights provided in Article 5 of the African Charter on Human and Peoples' Right (Ratification and Enforcement) Act, hence any occurrence that results in exploitation of human person, torture, harassment, humiliation and threat of any form, is highly condemnable. The government has a role to play in safeguarding and protecting citizens from degrading treatment arising from private individual, private organisations, law enforcement agencies, public institution and so on.

In HADIJA TOU MANI KARAOU v. THE REPUBLIC OF NIGER, [9] the court having found that the Republic of Niger failed to protect the plaintiffs right in regards to the practice of slavery as a result of which the plaintiff suffered undeniable physical, psychological and moral harm, held that she is entitled to an all-inclusive relief in reparation for the harm suffered and awarded 10,000,000 Francs CFA.

4. Consequently, the loss of life of a citizen as a result of government's negligence or neglect of utility duties spells further doom to the dependants of the deceased. The Community Court of Justice of ECOWAS in 2015 held in the case of HEMBADOON CHIA \& ORS V. FEDERAL REPUBLIC OF NIGERIA \& ANOR [10] that everyone has the right to education and this right is guaranteed under Article 17 (1) of the African Charter on Human and Peoples' Rights and other international human rights law. This by implication means, if the breadwinner of a family or group of people dies as a result of the state of insecurity in the country, the government is liable for compensation and continuing sustenance of the dependants of the deceased, especially the deceased children's education as a matter of right as provided in Article 17 (1) of the African Charter on Human and Peoples' Rights (Ratification and Enforcement) Act.

\section{Government Liability}

It has earlier been analysed in this article that the agreement between the government and citizens is that of a social contract wherein the citizens surrendered their rights to the government, who in turn will see to the protection and safeguard of the citizens' rights. It has also been stated in the earlier part of this article that even though the cause of death may not be associated to the acts of government or any of her agencies, the government still has the duty to protect citizens, and thoroughly investigate any occurrence of human rights violation. The next question therefore is, to what extent is the government liable for the widespread national insecurity in the country? Admittedly, the acts of banditry, killings and kidnapping may not be directly caused by the government nor any of the government agencies directly involved in the acts, however it is always the duty of the government to set the machinery in motion to investigate these and cause immediate prosecution for those found culpable.

In the case of CHIA AND ORS v. NIGERIA, [11] the Community Court of ECOWAS held that, a state has a legal duty to take responsible steps to prevent human rights violations and to use the means at its disposal to carry out serious investigation of violations committed within its jurisdiction to identify those responsible, impose appropriate punishment and ensure the victim's adequate compensation. This obligation requires that states maintain mechanisms and procedures through which investigations can be initiated.

Furthermore, a major hurdle that may not be too difficult to cross is, what constitutes proper investigation and what standards can be used to measure if investigation has been thoroughly conducted or not. The quick and apt answer to this was given by the court in MAKARATZIS v. GREECE, supra where the European Court held that,

investigation must be capable, firstly, of ascertaining the circumstances in which the incident took place, and secondly, of leading to the identification and punishment of those responsible. This is not an obligation of result, but of means. The authorities must have taken the reasonable steps available to them to secure the evidence concerning the incident, including, inter alia, eyewitness testimony and forensic evidence. A requirement of promptness and reasonable expedition is implicit in this context. Any deficiency in the investigation which undermines its capability of establishing the circumstances of the case or the person responsible is liable to fall foul of the required standard of effectiveness.

Having established the liability of government in protecting citizen's life, a major challenge is the enforcement of right of life and holding government accountable for lives lost as a result of insecurity in Nigeria. The major challenge has been the issue of locus standi. Nigerian courts have several times thrown away applications to enforce the right to life of a deceased person by a relative or any other person. The reason for this has always been that the applicant lacks the locus standi to institute such action under the fundamental right rules and also under Section 46 (1) of the Constitution of the Federal Republic of Nigeria 1999 (As Amended). This trend is archaic and has led to enormous absurdity. If the court still insists that only the subject of an infringement to life can be given redress, that implies that the entire essence of Chapter Four (4) of the Constitution is defeated. Meanwhile, more often than not, the victim of the violation of right to life is deceased at the time of filing the action. The parents or relatives of the deceased will apparently be directly affected; hence they fall under the purview of persons who can seek redress under Section 46 (1) of the Constitution.

The issue of whether a deceased person is a juristic person who is capable of enforcing his fundamental right does not apply here. The case of NASIRU BELLO v. AG OYO STATE [12] is very instructive in this regard, where KARIBI-WHYTE, JSC said an action will lie for the violation of the right to life by or on behalf of any person who has an interest in the continued existence of the deceased. The above decision has cured the notion that rights in Section 33, 34, 35, 36, and 41 of the Constitution are personal rights which cannot be transferred to another person. The distinction between next of kin and a real victim instituting an action in other claims does not apply in 
fundamental rights proceedings which are special. SALAMI, JCA even held in AHMAD v. SSHA [13] that there is no limitation or qualification to the nature of persons who may seek to enforce contravention of their rights under Chapter Four (4) of the Constitution. The court further clarified this issue in the case of DILLY v. IGP \& ORS [14] that,

"the right to life of a dead person can be litigated in the court. Failure to address such violation will create a monstrous situation where infractions will continue unabated and without redress thereby reducing such fundamental rights to chasing shadows or holding the mind. And definitely, it will be contrary to the constitutionally guaranteed right to life, the Africa Charter on Human and Peoples Rights and United Nations Universal Declaration of Human Rights, 1948. No court should be part of such retrogressive jurisprudence of human rights."

Also, the court in OMONYAHUY v. IGP [15] held that the criminality involved in the act of unlawful killing of the deceased Azeez Omotosho does not deprive the Respondents from maintaining an action to enforce their constitutionally guaranteed right to dignity of human person. Meanwhile, the Court of Appeal followed this line of view recently in the case of NPF \& ORS v. OMOTOSHO \& ORS [16] when the court was faced with the question of whether the constitutional right of life of a dead man can be enforced by his family and relatives. The answer to the question was in the affirmative to the extent that the court affirmed that the deceased family were entitled to award of damages in their favour for the proven infringement of their fundamental rights. In essential, the strict application of the doctrine of locus standi does not apply to matters on fundamental rights.

\section{Conclusion}

It is no longer news that Nigeria is currently experiencing high level of insecurity, mostly in the form of killing, banditry, ethnic clashes, and kidnapping. This is a wakeup call, especially to the government to live up to her expectations on protecting the lives and safeguarding the welfare of the citizens. It is crystal clear that the era has come for government to be held accountable for incessant killings across the country. The government has often times being excused of liability, especially when the cause of death is not directly connected with any of the government's agencies. This trend is no longer acceptable because the security and welfare of lives and properties remains the primary purpose of government. The citizens have entered a social contract with the government and have surrendered their rights to the government, and the government should in return secure and safeguard these rights. Citizens' lives should constantly be protected and in the event of unjust killings, the government should conduct thorough investigation and ensure the culprits are brought to justice.

\section{References}

[1] Scott Clark (2007) Solitary, Poor, Nasty, Brutish, and Short? Heidelblog. Retrieved 30 March 2021, from https://heidelblog.net/2007/12/solitary-poor-nasty-brutish-andshort/

[2] See John Simmons, (1989) Locke's State of Nature. Political Theory, 17 (3) 449-470.

[3] Constitution of the Federal Republic of Nigeria 1999 (As Amended).

[4] Suit no. ECW/CCJ/APP/03/14

[5] See Edwin Egede, (2007) Bringing Human Rights Home: An Examination of the Domestication of Human Rights Treaties in Nigeria. Journal of African Law 51 (2), 249-284.

[6] (1992) AIR 185.

[7] Series C No 125, [2005] 1 ACHR6.

[8] 50385/99 (delivered on 20 December, 2004).

[9] (2004-2009 CCJELR 217@242).

[10] $(\mathrm{ECW} / \mathrm{CCJ} / \mathrm{APP} / 07 / 16)$.

[11] (ECW/CCJ/APP/07/16 [2018] ECOWASCJ 21.

[12] (1986) 5 NWLR (PT. 45) 828.

[13] (2002) 15 NWLR (PT. 791) 539 at 563.

[14] (CA/C/12/2103) [2016] NGCA 21.

[15] (2015) LPELR (25581) 1 at 70.

[16] (2018) LPELR-45778 (CA). 